\title{
A new species and a new record of Heisteria Jacq. (Olacaceae s.l.) from the Atlantic Forest of Espírito Santo, Brazil
}

\author{
Danielly da Silva Lucena* (1) and Marccus Alves ${ }^{2}$ (1)
}

Received: October 1, 2020

Accepted: February 15, 2021

\begin{abstract}
During taxonomic studies of extra-Amazonian species of Heisteria, a new record (Heisteria maytenoides) and new species (Heisteria longipedicellata) from the Atlantic Forest of Espírito Santo were identified. Morphological descriptions, illustrations, the geographic distribution, and conservation status are provided for these species; an identification key for species of Heisteria of the state is also presented. Heisteria longipedicellata is known only from the type locality and recognized mainly by the long pedicel of the fruits (ca. $67 \mathrm{~mm}$ long). It is morphologically similar to $H$. blanchetiana, however, it differs by the length of the pedicel in fruit, diameter of the accrescent calyx in fruit and drupe size. Heisteria maytenoides, until now registered only in the phytogeographic domain of the Amazon in Colombia and Venezuela, had its distribution confirmed to Brazil, in the phytogeographic domain of the Atlantic Forest, in the state of Espírito Santo; it is recognized mainly by its coriaceous leaves and globoid fruits. In this study the richness of Heisteria for the Espírito Santo state is updated to five species. Heisteria blanchetiana, previously registered only to the state of Bahia, had its distribution expanded to include Espírito Santo.
\end{abstract}

Keywords: Atlantic Forest, Espírito Santo, biodiversity hotspot, Santalales, taxonomy

\section{Introduction}

Heisteria is the second most representative genus in Olacaceae s.l., composed of 34 species distributed in North and South America (31 spp.) and in Africa (3 spp.). The Neotropical region is the center of diversity for the genus and Brazil has the greatest richness, with 21 species (Sleumer 1984; Gentry 1993; Christenhusz et al. 2017), distributed in the phytogeographical domains of the Amazon, Caatinga, Cerrado and Atlantic Forest. The Amazonian domain is the most expressive with 17 species, followed by the Atlantic Forest, with five species registered so far (Flora do Brasil 2020 2020).
Heisteria species are trees, shrubs or rarely lianas. Members of the genus are morphologically characterized by their simple, alternate, glabrous and discolorous leaves, with inconspicuous latex, entire and often revolute margins, canaliculate petioles, often thicker in their upper half and slightly curved. Inflorescences are arranged in axillary fascicles, with up to 20 flowers, sessile or pedicellate, subtended by two to three bracts at the base, calyx cupulate, small at anthesis and accrescent in fruit. The fruits are drupes with a single seed and a persistent, expanded and colorful calyx (Sleumer 1984; Kuijt 2015).

In general, species of Heisteria are morphologically very similar to each other, as mentioned by Engler (1872) and Sleumer (1984). Flowers are morphologically homogeneous,

1 Programa de Pós-Graduação em Biologia Vegetal, Departamento de Botânica, Universidade Federal de Pernambuco, 51930-670, Recife, PE, Brazil 2 Departamento de Botânica, Universidade Federal de Pernambuco, 51930-670, Recife, PE, Brazil

\footnotetext{
* Corresponding author: botanicadane@gmail.com
} 
except for the length of the pedicel and number of stamens (10-12, rarely 5-6). Species are distinguished mainly by a combination of leaf and fruit characters. Leaf morphological characters such as texture, shape, size and color when dried, number of secondary veins and the pattern of reticulation are taxonomically important at the species level in Heisteria (Sleumer 1984), as well as the shapes of the fruit, diameter of the persistent calyx and the length of the pedicel.

During taxonomic studies of extra-Amazonian species of Heisteria, a new record for Brazil (H. maytenoides) and a new species have been identified in the Atlantic Forest of Espírito Santo. Morphological descriptions, illustrations, information about the geographic distribution and conservation status are provided for these species, and an identification key for the other species of the genus recorded in Espírito Santo state are also presented.

\section{Materials and methods}

This paper is part of the taxonomic studies of the extraAmazonian species of Heisteria Jacq. for which specimens from the following herbaria were consulted: ALCB, *ASU, ${ }^{*} \mathrm{BM},{ }^{*} \mathrm{BR}, \mathrm{CEN},{ }^{*} \mathrm{CESJ}, \mathrm{CEPEC},{ }^{*} \mathrm{COAH}, \mathrm{EAC}, \mathrm{EAN}, \mathrm{ESA},{ }^{*} \mathrm{~F}$, FLOR, FURB, HB, ${ }^{*} \mathrm{HCF}, \mathrm{HST}, \mathrm{HUEFS}, \mathrm{IPA}, \mathrm{JPB},{ }^{*} \mathrm{~K},{ }^{*} \mathrm{~L}, \mathrm{M}$, MAC, MBML, MBM, ${ }^{*} M O,{ }^{*} N Y$, PEUFR, R, RB, SPSF, SP, SPF, ${ }^{*} \mathrm{TCD},{ }^{*} \mathrm{U}, \mathrm{UB}, \mathrm{UFRN}, \mathrm{UFP}, \mathrm{UPCB},{ }^{*} \mathrm{US}$ and VIES (acronyms according to Thiers 2020 (continuously updated), except, HST (Herbário Sérgio Tavares) - Universidade Federal Rural de Pernambuco). For the herbaria marked with asterisks, only images were seen.

Morphological descriptions were elaborated based on herbarium specimens, following Stearn (1995) and Harris and Harris (2000). Protologs, local floras and taxonomic reviews (Sleumer 1984; Cabral \& Agra 1999; Ribeiro et al. 1999; Rodrigues \& Rossi 2002; Assis 2004; Meirelles \& Fernandes Junior 2017) were also consulted. Data on geographic distribution, habitat, and phenology were obtained from specimen labels. A preliminary conservation status was proposed for these two species based on the criteria and categories established by the IUCN (2017), the extent of occurrence (EOO) and area of occupancy (AOO) were evaluated by GeoCat software (Bachman et al. 2011), using only occurrence points of samples with confirmed identification. The geographic distribution map was elaborated using Quantum Geographic System (QGIS), v.2.18.6 (QGIS Development Team 2015).

\section{Results and discussion}

\section{Taxonomic treatment}

1. Heisteria longipedicellata D.S. Lucena \& M. Alves, sp. nov. Type: BRAZIL. Espírito Santo: Itapemirim, região do Gomes, 23 October 2000, G. Hatschbach, M. Hatschbbach, J.M. Silva, 71534 (Holotype, M - 0244279!).

Heisteria longipedicellata is morphologically similar to $H$. blanchetiana (Engl.) Sleumer, including by the length of the pedicel in the flowers (ca. 3 vs. 3-5 mm in H. blanchetiana), however it differs by the length of the pedicel in fruit (ca. 67 vs. 7-12 mm long), diameter of the accrescent calyx in fruits (ca. 25 vs. $45-70 \mathrm{~mm}$ ) and drupe size $(7-11 \times 5-7$ vs. $11-14 \times 9-11 \mathrm{~mm})$.

Trees, 2-5 $\mathrm{m}$ tall. Branches glabrous, longitudinally striate. Leaves chartaceous, simple, alternate, glabrous; petiole $6-15 \mathrm{~mm}$ long, cylindrical, canaliculate, glabrous, longitudinally striate; blades $12-16 \times 3.5-5.5 \mathrm{~cm}$, oblong to lanceolate, adaxial surface dull, base rounded to cuneate, apex acute to acuminate, margin entire, venation brochidodromous, main midrib flat to lightly impressed on adaxial surface and prominent on abaxial surface, secondary veins $8-12$, flat on adaxial surface, prominent on abaxial surface. Inflorescences in axillary fascicles, sessile, bearing 12-15 flowers. Flowers bisexual; bracts 2-3, ca. 2 mm long, triangular; pedicel ca. $3 \mathrm{~mm}$ long; calyx lobes alternating with the corolla lobes, 5 -merous, connate up to $0.2 \mathrm{~mm}$ long, lobes $1 \mathrm{~mm}$ long, triangular, apex acuminate, margin papillate; corolla 5-merous, petals ca. $1.2 \times 0.4 \mathrm{~mm}$, free, ovate, villous up to the middle portion on adaxial surface; stamens 10, 5 shorter and opposite the petals, filaments 0.3-0.4 $\mathrm{mm}$ long, 5 longer and alternating with the petals, filaments $0.6-0.7 \mathrm{~mm}$ long, anthers $0.2 \mathrm{~mm}$ long, basifixed, subglobose, rimose; gynoecium $1 \mathrm{~mm}$ long, stigma slightly trilobed, ovary superior, depressed-globose, glabrous, 4-locular, 4-ovulate. Drupe 7-11 × 5-7 mm, oblongoid, longitudinally striated, apex apiculate; calyx accrescent, ca. $25 \mathrm{~mm}$ diam., deeply lobed, 5-lobed, connate at base up to $4-5 \mathrm{~mm}$, lobes free $9 \times 11 \mathrm{~mm}$, apex rounded to acute, pedicel ca. $67 \mathrm{~mm}$ long (Fig. 1).

Distribution and Habitat: The species is known only from the type locality: the region of Gomes, in the municipality of Itapemirim, Espírito Santo state (Fig. 2). No precise geographic coordinates are available on the herbarium label. The locality (Region of Gomes) suggests that the type locality is a fragment of Restinga forest located between Lagoa do Guanandy, also called Lagoa do Gomes or Lagoa das Sete Pontas and Praia da Marinha. This area is composed of a mosaic of vegetation types, including herbaceous, shrub and forest formations, both spaced and dense. The site presents stretches of flooded soils, pasture areas and small fragments in the process of natural regeneration (Leite 2010).

Phenology: It was found with flowers and fruits in October.

Etymology: The specific epithet of this new species refers to the exceptionally long and accrescent pedicel of the fruit (ca. $67 \mathrm{~mm}$ long), which in other species of Heisteria ranges from 1 to $20 \mathrm{~mm}$ long (Sleumer 1984). 

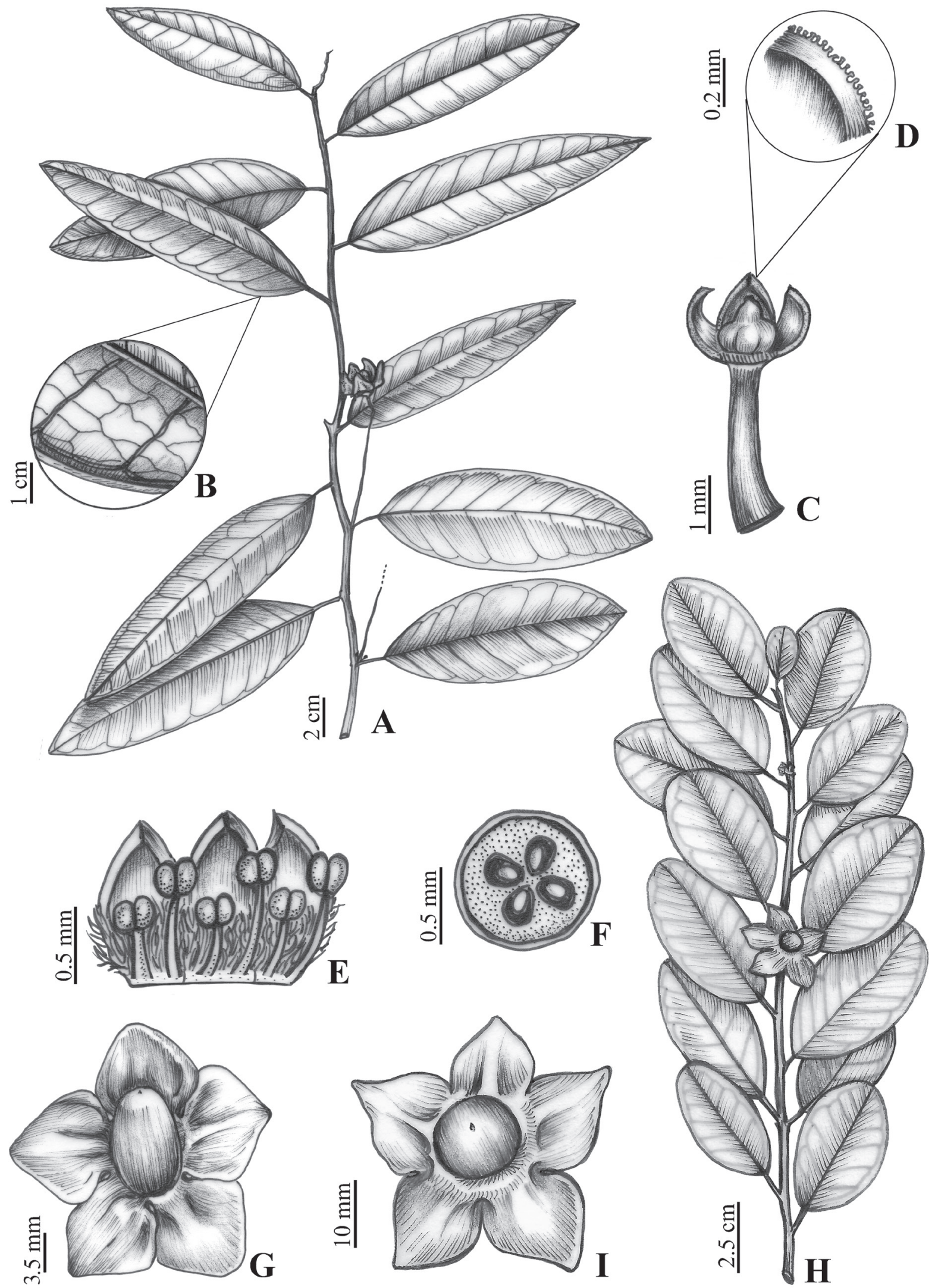

Figure 1. A-G. Heisteria longipedicellata D.S. Lucena \& M. Alves. A. Reproductive branch. B. Detail of the secondary and tertiary veins. C. Pedicel, part of calyx and gynoecium. D. Detail of calyx margin. E. Part of corolla and androecium. F. Cross-section of the ovary showing locules and ovules. G. Fruit. (A-G, G. Hatschbach, M. Hatschbbach \& J.M. Silva 71534 (holotype M)). H-I. Heisteria maytenoides Spruce ex. Engl. H. Reproductive branch. I. Fruit (L. Kollmann 5462). Illustrated by Regina Carvalho. 
Conservation status and occurrence in Conservation Units: According to the criteria established by the IUCN (2017), if a taxon is known only from the type locality it is recommended to be included, even if provisionally, in category DD (data deficient), due to the absence of data to calculate the extent of occurrence (EOO) and the occupation area (AOO) of the taxon. Even so, it is important to mention that although inserted in the Área de Proteção Ambiental Lagoa do Guarandy (area of sustainable use), the locality where $H$. longipedicelata was collected is under strong anthropic pressure mainly due to sand extraction, selective cutting of wood and fires which constitute a threat to the conservation of local biodiversity, especially for endemic species (Leite 2010; Valadares \& Sakuragui 2016).

Observations: The type specimen is part of a set of samples with the same collection number (G. Hatschbach, M. Hatschbbach \& J.M. Silva 71534), previously identified as H. perianthomega (Vell.) Sleumer, and with duplicates distributed to several Brazilian herbaria, and also in the United States and Germany. However, two species are mixed, the samples deposited at ASU, CESJ, HCF, MBM, RB, SPF, SPSF and $U$ were analyzed and confirmed to fit under the circumscription of $H$. perianthomega (Vell.) Sleumer. The sample at $\mathrm{M}$ presents the stunning morphological feature of the long pedicel, which distinguishes it from the others and represents the new species of Heisteria describe here.

Heisteria longipedicellata is also morphologically similar to H. perianthomega (Vell.) Sleumer, mainly by the shape of the fruits. It differs by the slightly longer pedicel in the flowers (ca. 3 vs. 0.5-1 mm long in H. perianthomega) and exceptionally long one in fruit (ca. 67 vs. 4-7 mm long), as well as by a slightly smaller accrescent calyx diameter in the fruits (ca. 25 vs. 27-40 mm diam.). As mentioned in the diagnosis, Heisteria longipedicellata is similar to $H$. blanchetiana in terms of the length of the pedicel in the flowers, but when herborized samples of $H$. blanchetiana have the adaxial surface of the leaf blade shiny which is not seen in $H$. longipedicellata and can be helpful to identify specimens with flowers or immature fruits. The other species of Heisteria that occur in the state of Espírito Santo are easily differentiated from $\mathrm{H}$. longipedicellata, as can be seen below in the identification key.

2. Heisteria maytenoides Spruce ex Engl. Fl. Bras. (Martius) 12 (2): 15 (1872). Type: VENEZUELA/COLOMBIA. Guainia vel Rio Negro supra ostium fluminis Casiquiari, 1854, R. Spruce 3508 (Holotype: BR [Barcode BR528997; digital image]!; Isotypes: BM [BM000839920; digital image]!, K [K000584506; digital image]!, MO [MO1624771; digital

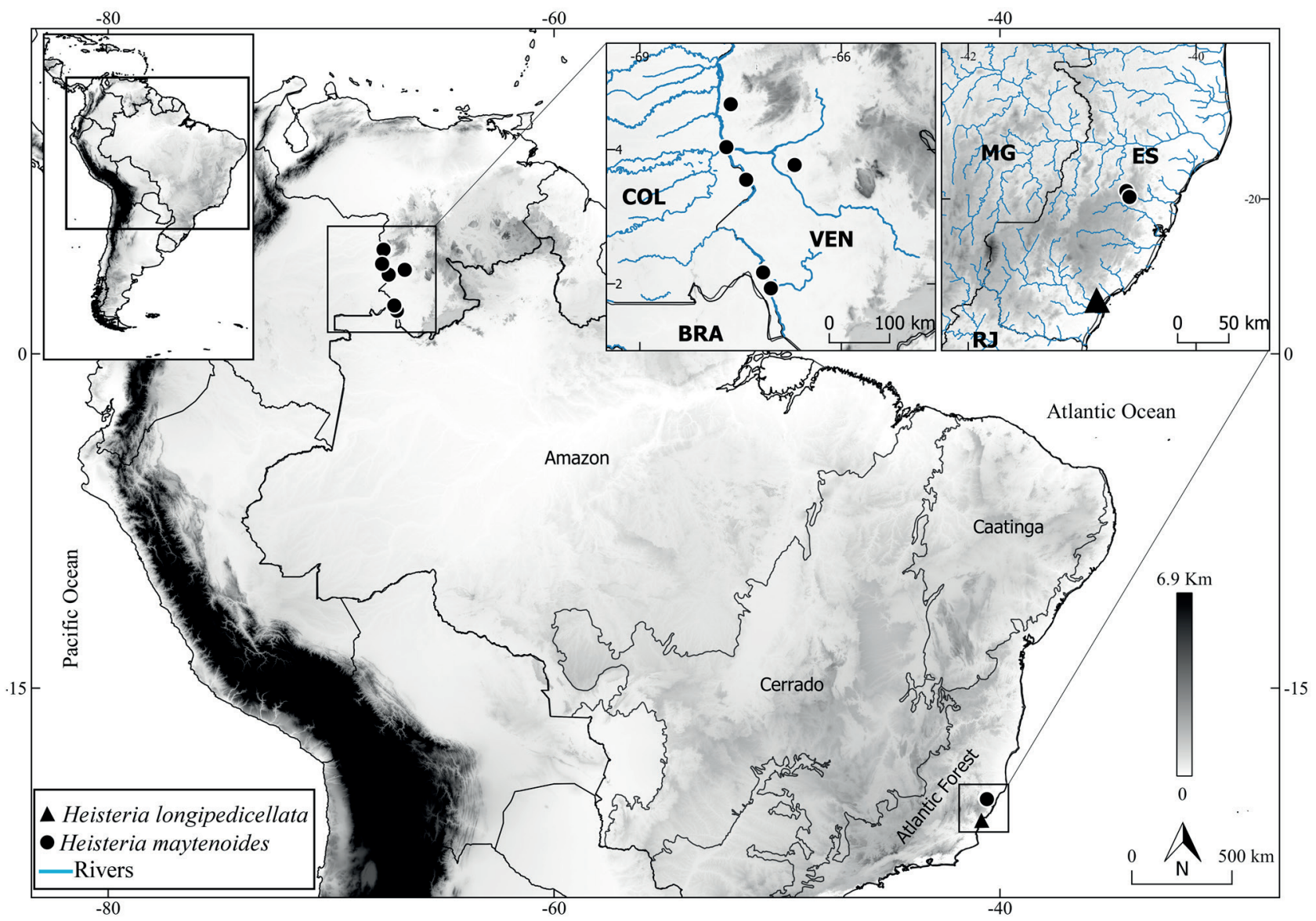

Figure 2. Geographical distribution of Heisteria longipedicellata D.S. Lucena \& M. Alves and Heisteria maytenoides Spruce ex. Engl. ES (Espírito Santo), MG (Minas Gerais), RJ (Rio de Janeiro). 
image]!, NY [NY00285475; digital image]!, P [P02441921; digital image]!, TCD [TCD0004101; digital image]!).

Trees, 3-15 m tall. Branches glabrous, longitudinally striate on younger parts. Leaves coriaceous, simple, alternate, glabrous; petiole 5-11 mm long, cylindrical, canaliculate, glabrous, longitudinally striate; blades $5.5-8.5(-11.5)$ $\times(2.7-) 3-4.1 \mathrm{~cm}$, oblong, elliptical, adaxial surface dull, base cuneate, apex acute, margin entire, venation brochidodromous, main midrib flat to lightly impressed on adaxial surface and prominent on abaxial surface, secondary veins $7-10$, flat and inconspicuous on the adaxial and abaxial surfaces. Inflorescences in axillary fascicles, sessile, bearing 7-10 flowers. Flowers bisexual; bracts 2-3; ca. $2 \mathrm{~mm}$ long, triangular; pedicel 1-1.5 mm long; calyx lobes alternating with the corolla lobes, 5-merous, connate up to $0.2 \mathrm{~mm}$ long, lobes $1.5 \mathrm{~mm}$ long, triangular, apex acuminate, margin papillate; corolla 5-merous, petals ca. $1.8 \times 1 \mathrm{~mm}$, free, lanceolate, villous up to the middle portion on the adaxial surface; stamens 10, 5 shorter and opposite the petals, filaments ca. $0.5 \mathrm{~mm}$ long, 5 longer and alternating with the petals, filaments ca. $0.9 \mathrm{~mm}$ long, anthers $0.5 \mathrm{~mm}$ long, basifixed, slightly quadrangular, rimose; gynoecium $1 \mathrm{~mm}$ long, stigma slightly trilobed, ovary superior, depressedglobose, glabrous, 4-locular, 4-ovulate. Drupe, when mature $12 \times 13 \mathrm{~mm}$, globoid, longitudinally striated, apex apiculate; calyx accrescent, 37-55 mm diam., deeply lobed, 5-lobed, connate at base up to $7-9 \mathrm{~mm}$, lobes free $11 \times 11 \mathrm{~mm}$, apex acute, involving the fruits when immature and patent when mature, pedicel ca. $15 \mathrm{~mm}$ long (Fig. 1).

Distribution and Habitat: In this study, H. maytenoides is confirmed to Brazil, Colombia and Venezuela (Fig. 2). In Colombia and Venezuela, it is distributed along the banks of the upper Rio Negro, in the department of Guainía and in the state of Amazonas, respectively. It is an area inserted in the Amazon domain, with altitudes ranging from 120 to 150 meters asl with sandy, flooded, light-colored and nutrient-poor soils. The vegetation is characterized mainly by having spaced trees, with small diameter trunks and canopies, and often bearing coriaceous leaves (Anderson 1981; Adeney et al. 2016; Kvarnbäck \& Bosque 2017).

In Brazil, records of this species have been confirmed so far only for the Atlantic Forest domain, in the state of Espírito Santo, in two locations of Dense Ombrophilous Forest, with altitudes ranging from 700 to 950 meters asl. The specimens were collected in the basin of the Rio Bonito and in the Parque Natural Municipal de São Lourenço, an area cut by numerous streams that flow into Rio São Lourenço. Heisteria species commonly grow close to streams and small rivers, as is the case in the area of the new record of $H$. maytenoides.

Ramos (2020) listed this species to the Brazilian Amazon domain. However, the specimens cited by the author (JA Silva 207 and EG Holt \& ER Blake 576) correspond to $H$. amazonica Sleumer and $H$. duckei Sleumer, respectively. MacDougal (2003) also mentions the distribution of
H. maytenoides as Brazil, Colombia and Peru, but the samples analyzed from Brazil (EG Holt \& ER Blake 576) and Peru (V. Huashikat 337) do not correspond to this species but to $H$. duckei and $H$. ovata Benth, respectively.

With a distribution along the banks of the Rio Negro and close to the border with the Brazilian territory, it is possible that this species also occurs in the Brazilian Amazon domain, but so far, no record has been found in the collections analyzed. A disjunct distribution of $H$. maytenoides is confirmed here to the Amazonian domain, Colombia and Venezuela, and to the Atlantic Forest domain in Brazil, a pattern already reported for several botanical families and for other genera of Olacaceae (Rizzini 1963; Prance 1982; Fiaschi \& Pirani 2009; Turchetto-Zolet et al. 2012).

Phenology: It was collected with flowers and fruits in January, and only with fruits between May and July. It has cream to greenish flowers and green fruits with the accrescent calyx an intense red.

Conservation status and occurrence in Conservation Units: This species has an occupation area of less than $500 \mathrm{~m}^{2}$, occurring in few localities, and with a reduced number of mature individuals known to date. According to the criteria established by IUCN (2017), $H$. maytenoides Spruce is indicated as Endangered (EN) [B2b (ii, iv)].

In this study, two specimens were cataloged in Conservation Units in Venezuela (Reserva Forestal El Sipapo) and Brazil (Parque Natural Municipal São Lourenço), showing the importance of these areas in the preservation of this species.

Observations: Heisteria maytenoides differs from other species that occur in the state of Espírito Santo State by its coriaceous leaves, flat and inconspicuous secondary veins on the abaxial surface and globoid drupes. Among the collections studied, some species of Heisteria are misidentified as $H$. maytenoides. They actually are $H$. duckei, $H$. amazonica or $H$. ovata. However, H. maytenoides is easily differentiated from $H$. duckei, mainly by the shape of the blade (oblong to elliptical vs. obovate to rarely elliptical in H. duckei) and leaf apex (acute vs. strongly acuminate), as well as the shape of the fruits (globoid vs. ellipsoid); from $H$. amazonica by the shape of the leaf apex (acute $v s$. acuminate in H. amazonica) and lateral veins (flat and inconspicuous on the abaxial surface $v s$. prominent on abaxial surface), and from $H$. ovata by the shape of the fruit (globoid $v$ s. frequently oblongoid in $\mathrm{H}$. ovata) and the diameter of the accrescent calyx in the mature fruits (37-55 mm vs. $10-25 \mathrm{~mm}$ ).

Specimens Examined: BRAZIL. Espírito Santo: Santa Teresa, Cabeceira do rio bonito, 31 January 2002, L. Kollmann 5462 (HUEFS!, MBML!); Santa Teresa, Parque Natural Municipal de São Lourenço, 16 May 2003, T.A. Cruz 65 (MBML!). COLOMBIA. Guainía, Inírida, 09 May 2007, D. Cárdenas et al. 20560 (NY [digital image]!). VENEZUELA. Amazonas, 6-19 July, G.S. Bunting, L.M.A. Akkermans \& 
J.V. Rooden 4064 (U [digital image]!); Rio Orinoco opposite mouth of Rio Atabapo, 05 June 1959, J.J. Wurdack \& L.S. Adderley 42811 (U [digital image]!, F [digital image]!, US [digital image]!); Rio Orinoco, Yapacana, 17 June 1959, J.J. Wurdack \& L.S. Adderley 43017 (US [digital image]!); Reserva Florestal El Sipapo, May 1971, C. Blanco 1134 (US [digital image]!); San Carlos de Rio Negro, 08 May 1980, H.L. Clark \& P. Maquirino 7990 (L [digital image]!).

In addition to Heisteria longipedicellata and $H$. maytenoides, other species of Heisteria are registered for the state of Espírito Santo, such as H. blanchetiana,
H. perianthomega and H. silvianii Schwacke. During this study, the richness of Heisteria for the state was updated, from two ( $H$. perianthomega and $H$. silvianii) to five species. Heisteria blanchetiana previously registered only to the state of Bahia, mainly in gallery forests in the Cerrado domain (Sleumer 1984; Flora do Brasil 2020 2020), is now expanded to Espírito Santo State. The number of species of Heisteria for the Brazilian Atlantic Forest domain has also been increased from five (Flora do Brasil 2020 2020) to seven species. An identification key for Heisteria species that occur in the state of Espírito Santo is provided below.

\section{Key to the species of Heisteria occurring in Espirito Santo}

1 . Secondary veins $\geq 18$; floral pedicel $5.5-7 \mathrm{~mm}$ long; calyx in fruit slightly lobed

H. silvianii

1. Secondary veins $6-13$; floral pedicel $0.5-5 \mathrm{~mm}$ long; calyx in fruit deeply lobed 2

2. Leaves coriaceous, secondary veins flat and inconspicuous on the abaxial surface; drupes globoid.

H. maytenoides

2. Leaves chartaceous, secondary veins prominent and conspicuous on the abaxial surface; drupes oblongoid, ovoid or subgloboid

3. Adaxial surface of the leaf blade shiny; floral pedicel 3-5 mm long; calyx in fruit $45-70 \mathrm{~mm}$ diam ........ H. blanchetiana

3. Adaxial surface of the leaf blade dull; floral pedicel $0.5-3 \mathrm{~mm}$ long; calyx in fruit $25-40 \mathrm{~mm}$ diam .

4. Floral pedicel 0.5-1 $\mathrm{mm}$ long; pedicel in the fruit 4-7 $\mathrm{mm}$ long, calyx in fruit 27-40 mm diam .... H. perianthomega

4. Floral pedicel ca. $3 \mathrm{~mm}$ long; pedicel in the fruit ca. $67 \mathrm{~mm}$ long, calyx in fruits ca. $25 \mathrm{~mm}$ diam ..... H. longipedicellata

\section{Acknowledgements}

The authors thank the curators and technicians of the herbaria visited, especially Dr. Vinicius Antonio de O. Dittrich (CESJ), Dr. Marcelo Galeazzi Caxambu and Dr. Greta Aline Dettke (HCF), Dr. Hans-Joachim Esser and Andreas Fleischmann (M) for sending the high-resolution photographs. The authors also thank the Conselho Nacional de Desenvolvimento Científico e Tecnológico (CNPq) for awarding a grant to the first author and Coordenação de Aperfeiçoamento de Pessoal de Nível Superior - Brasil (CAPES) - Finance Code 001.

\section{References}

Adeney JM, Christensen NL, Vicentini A, Cohn-Haft M. 2016. White-sand Ecosystems in Amazonia. Biotropica 48: 7-23.

Anderson AB. 1981. White-Sand Vegetation of Brazilian Amazonia. Biotropica 13: 199-210.

Assis MC. 2004. Flora de Grão-Mogol, Minas Gerais: Olacaceae. Boletim de Botânica da Universidade de São Paulo 22: 349-351.

Bachman S, Moat J, Hill AW, Torre JL, Scott B. 2011. Supporting red list threat assessments with GeoCAT: Geospatial conservation assessment tool. ZooKeys 150: 117-126.

Cabral S, Agra MFA. 1999. Flora paraibana: Olacaceae mirb. ex DC. Revista Nordestina de Biologia 13: 1-11.

Christenhusz MJM, Fay MF, Chase MW. 2017. Plants of the world. Chicago, Royal Botanic Gardens.

Engler A. 1872. Olacineae. In: Martius CFP, Eichler AG, Urban I. (eds.). Flora brasiliensis. Vol 12. Part. II. Lipsiae, Frid. Fleischer. http://florabrasiliensis.cria.org.br/search?taxon_id=6342.19Jul. 2020.
Fiaschi P, Pirani JR. 2009. Review of plant biogeographic studies in Brazil. Journal of Systematics and Evolution 47: 477-496.

Flora do Brasil. 2020. 2020. Rio de Janeiro, Jardim Botânico do Rio de Janeiro, Brazil. http://floradobrasil.jbrj.gov.br/. 16 Jul. 2020.

Gentry AH. 1993. A field guide to the families and genera of woody plants of Northwestern South America (Colombia, Ecuador, Peru): With supplementary notes on herbaceous taxa. Washington, Conservation International.

Harris JG, Harris MW. 2000. Plant identification terminology, an illustrated glossary. Spring Lake, Utah, Spring Lake Publishing.

IUCN. 2017. IUCN red list categories and criteria version 13. Gland, Switzerland, Cambridge, UK, IUCN.

Kvarnbäck JF, Bosque C. 2017. An Inventory of the birds of White-sand vegetation of Guainía / Rio Negro basin, Southern Amazonas State, Venezuela. BioLlania 15: 533-560.

Kuijt J. 2015. Santalales. In: Kubitzki K. (ed.) The Families and Genera of Vascular Plants. Vol. XII. Berlin, Springer Verlag. p. 127-136.

Leite VR. 2010. Análise estrutural e da vulnerabilidade ambiental de um fragmento de restinga ao sul do estado do Espírito Santo. MSc Thesis, Universidade Federal do Espírito Santo, Jerônimo Monteiro.

MacDougal JM. 2003. Olacaceae. In: Steyermark JA, Berry PE, Yatskievych K, Holst BK. (eds.) Flora of the Venezuelan Guayana. St Louis, Missouri Botanical Garden. p. 162-186.

Meirelles J, Fernandes Júnior AJ. 2017. Flora of the cangas of Serra dos Carajás, Pará, Brazil: Olacaceae. Rodriguésia 68: 1053-1057.

Prance GT. 1982. Forest Refuges: Evidence from Woody Angiosperms. In: Prance GT. (ed.) Biological Diversification in the Tropics. New York, Columbia University Press. p. 137-158.

QGIS Development Team. 2015. QGIS Geographic Information System. Open Source Geospatial Foundation Project. http://qgis.osgeo.org. 08 Jun. 2020.

Ramos RS. 2020. Heisteria Jacq. (Olacaceae) na Amazônia brasileira. MSc Thesis, Universidade Federal Rural da Amazônia, Belém.

Ribeiro JELS, Hopkins MJG, Vicentini A, et al. 1999. Flora da Reserva Ducke: Guia de identificação das plantas vasculares de uma floresta de terra firme na Amazônia central. Manaus, INPA. 


\section{Danielly da Silva Lucena and Marccus Alves}

http://www.botanicaamazonica.wiki.br/labotam/lib/exe/fetch.php?med ia=reservaducke:pfrd:guia:000_glossario_1_contracapa_e_indice_5.pdf. Rizzini CT. 1963. Nota prévia sobre a divisão fitogeográfica (Florísticosociológica) do Brasil. Revista Brasileira de Geografia 25: 3-64.

Rodrigues EA, Rossi L. 2002. Olacaceae. In: Wanderley MGL, Shepherd GJ, Giulietti AM, Melhem TS, Bittrich V, Kameyama C. (eds.) Flora fanerogâmica do estado de São Paulo. 2nd. edn. São Paulo, Instituto de Botânica. p. 213-218.

Sleumer HO. 1984. Olacaceae: Flora Neotropica Monograph. Bronx, New York Botanical Garden.

Stearn WT. 1995. Botanical Latin. 4th. edn. Portland, Timber Press.
Thiers B. 2020 (continuously updated). Index Herbariorum: a global directory of public herbaria and associated staff. New York Botanical Garden's Virtual Herbarium. http://sweetgum.nybg.org/science/ih/.08 Jun. 2020.

Turchetto-Zolet AC, Fernanda C, Vendramin GG, et al. 2012. Large-scale phylogeography of the disjunct Neotropical tree species Schizolobium parahyba (Fabaceae-Caesalpinioideae). Molecular Phylogenetics and Evolution 65: 174-182.

Valadares RT, Sakuragui CM. 2016. A família Araceae Juss. nas restingas do Estado do Espírito Santo. Boletim do Museu de Biologia Mello Leitão 38: 187-255. 